\title{
The mitochondrial genome of Paragyrodactylus variegatus (Platyhelminthes: Monogenea): differences in major non-coding region and gene order compared to Gyrodactylus
}

Fei Ye', Stanley D King ${ }^{2}$, David K Cone ${ }^{3}$ and Ping You ${ }^{1 *}$

\begin{abstract}
Background: Paragyrodactylus Gvosdev and Martechov, 1953, a viviparous genus of ectoparasite within the Gyrodactylidae, contains three nominal species all of which infect Asian river loaches. The group is suspected to be a basal lineage within Gyrodactylus Nordmann, 1832 sensu lato although this remains unclear. Further molecular study, beyond characterization of the standard Internal Transcribed Spacer region, is needed to clarify the evolutionary relationships within the family and the placement of this genus.
\end{abstract}

Methods: The mitochondrial genome of Paragyrodactylus variegatus You, King, Ye and Cone, 2014 was amplified in six parts from a single worm, sequenced using primer walking, annotated and analyzed using bioinformatic tools.

Results: The mitochondrial genome of P. variegatus is 14,517 bp, containing 12 protein-coding genes (PCGs), 22 transfer RNA (tRNA) genes, two ribosomal RNA (rRNA) genes and a major non-coding region (NCR). The overall $A+T$ content of the mitochondrial genome is $76.3 \%$, which is higher than all reported mitochondrial genomes of monogeneans. All of the 22 tRNAs have the typical cloverleaf secondary structure, except tRNA ${ }^{\text {Cys }}$, tRNA ${ }^{\text {Ser1 }}$ and tRNA ${ }^{\text {Ser2 }}$ that lack the dihydrouridine (DHU) arm. There are six domains (domain III is absent) and three domains in the inferred secondary structures of the large ribosomal subunit (rrnL) and small ribosomal subunit (rrnS), respectively. The NCR includes six 40 bp tandem repeat units and has the double identical poly-T stretches, stem-loop structure and some surrounding structure elements. The gene order (tRNA ${ }^{\mathrm{Gln}}$, tRNA ${ }^{\text {Met }}$ and NCR) differs in arrangement compared to the mitochondrial genomes reported from Gyrodactylus spp.

Conclusion: The Duplication and Random Loss Model and Recombination Model together are the most plausible explanations for the variation in gene order. Both morphological characters and characteristics of the mitochondrial genome support Paragyrodactylus as a distinct genus from Gyrodacty/us. Considering their specific distribution and known hosts, we believe that Paragyrodactylus is a relict freshwater lineage of viviparous monogenean isolated in the high plateaus of central Asia on closely related river loaches.

Keywords: Paragyrodactylus variegatus, Mitochondrial genome, Gyrodactylus, Gyrodactylidae, Monogenea, Homatula variegata, China

\footnotetext{
* Correspondence: youping@snnu.edu.cn

${ }^{1}$ Co-Innovation Center for Qinba regions' sustainable development, College

of Life Science, Shaanxi Normal University, Xi'an 710062, China

Full list of author information is available at the end of the article
} 


\section{Background}

Gyrodactylids are widespread parasites of freshwater and marine fishes, typically inhabiting the skin and gills of their hosts. Their direct life-cycle and hyperviviparous method of reproduction facilitates rapid population growth. Some species are pathogenic to their host (e.g. Gyrodactylus salaris Malmberg, 1957) [1] and capable of causing high host mortality resulting in serious ecological and economical consequences [2]. Over twenty genera and 400 species of gyrodactylids have been described [3], most of them being identified by comparative morphology of the opisthaptoral hard parts. This traditional approach for identification of gyrodactylids gives limited information for detailed phylogenetic analysis. Recently, the nuclear ribosomal DNA (rDNA) and the internal transcribed spacers (ITS) of rDNA have been incorporated into the molecular taxonomy of the group $[4,5]$. In addition, mitochondrial markers (COI and COII) are also confirmed to be DNA barcoding for Gyrodactylus Nordmann, 1832 $[6,7]$. But more polymorphic molecular markers suitable for different taxonomic categories are still needed for studying the taxonomy and phylogeny of these parasites.

Paragyrodactylus Gvosdev and Martechov, 1953 is a genus of Gyrodactylidae comprising three nominal species, Paragyrodactylus iliensis Gvosdev and Martechov, 1953 (=P. dogieli Osmanov, 1965), Paragyrodactylus barbatuli Ergens, 1970 and Paragyrodactylus variegatus You, King, Ye and Cone, 2014, all of which infect river loaches (Nemacheilidae) inhabiting streams in central Asia [8]. The relationship between Paragyrodactylus and Gyrodactylus has been recently explored. Kritsky and Boeger reported the two genera had a close relationship based on morphological characters [9]. Bakke et al. believed the complexity of the attachment apparatus separates Paragyrodactylus from Gyrodactylus and pondered whether these differences were fundamental or a local diversification within Gyrodactylus [3]. Furthermore, You et al., using morphology and molecular data, presented the hypothesis that Paragyrodactylus was a relict freshwater lineage of viviparous monogeneans isolated in the high plateaus of central Asia on river loaches [8]. The ambiguous relationship between Paragyrodactylus and Gyrodactylus emphasizes the need for further molecular study of these genera.

Due to its higher rate of base substitution, maternal inheritance, evolutionary conserved gene products and low recombination [10,11], mitochondrial genomes provide powerful markers for phylogenetic analysis, biological identification and population studies. In addition, mitochondrial genomes can provide genome-level characters such as gene order for deep-level phylogenetic analysis $[12,13]$. To date, the complete mitochondrial
DNA sequences of only nine monogeneans are available, including three species of Gyrodactylus.

In the present study, the first mitochondrial genome for Paragyrodactylus, P. variegatus, is sequenced and characterized. We report on its genome organization, base composition, gene order, codon usage, ribosomal and transfer RNA gene features and major non-coding region. Additionally, we provide a preliminary comparison of the gene arrangement within both Paragyrodactylus and Gyrodactylus.

\section{Methods}

\section{Specimen collection and DNA extraction}

Specimens of $P$. variegatus were collected from the skin and fins of wild Homatula variegata (Dabry de Thiersant, 1874) in the Qinling Mountain region of central China. Upon capture the specimens were immediately preserved in $99 \%$ ethanol and stored at $4{ }^{\circ} \mathrm{C}$. The DNA from one parasite was extracted using a TIANamp Micro DNA Kit (Tiangen Biotech, Beijing, China) according to the manufacturer's protocol.

\section{PCR and sequencing}

The complete mitochondrial genome of $P$. variegatus was amplified in six parts using a combination of existing primers and newly developed primers generated by primer walking (primers listed in Table 1). For short fragments $(<2 \mathrm{~kb})$, PCR reactions were performed in a total volume of $25 \mu \mathrm{l}$, containing $3.0 \mathrm{mM} \mathrm{MgCl}$, $10 \mathrm{mM}$ Tris- $\mathrm{HCl}$ (pH 8.3), $50 \mathrm{mM} \mathrm{KCl}, 0.25 \mathrm{mM}$ of each dNTP , 1.25 U rTaq polymerase (TaKaRa, Dalian, China), $0.4 \mu \mathrm{M}$ of each primer, $45 \mathrm{ng}$ gDNA. Cycling conditions were: an initial denaturation for $1 \mathrm{~min}$ at $93^{\circ} \mathrm{C}$, followed by 40 cycles of $10 \mathrm{sec}$ at $92^{\circ} \mathrm{C}, 1.5 \mathrm{~min}$ at $52-54^{\circ} \mathrm{C}, 2 \mathrm{~min}$ at $60^{\circ} \mathrm{C}$, and final extension of $6 \mathrm{~min}$ at $72^{\circ} \mathrm{C}$. For long fragments $(>2 \mathrm{~kb})$, the $25 \mu \mathrm{l}$ PCR reaction consisted of $2.5 \mathrm{mM} \mathrm{MgCl}_{2}, 2.5 \mu \mathrm{l} 10 \times \mathrm{LA}$ PCR Buffer II $\left(\mathrm{Mg}^{2+}\right.$ free), $0.4 \mathrm{mM}$ of each dNTP, $1.25 \mathrm{U}$ LA Taq polymerase (TaKaRa, Dalian, China), $0.4 \mu \mathrm{M}$ of each primer, 45 ng gDNA. Cycling conditions were: an initial denaturation for $1 \mathrm{~min}$ at $94^{\circ} \mathrm{C}$, followed by 40 cycles of $20 \mathrm{sec}$ at $93^{\circ} \mathrm{C}, 30 \mathrm{sec}$ at $53-54^{\circ} \mathrm{C}, 4-7 \mathrm{~min}$ at $68^{\circ} \mathrm{C}$, and final extension of $10 \mathrm{~min}$ at $68^{\circ} \mathrm{C}$. All PCR products were purified with a PCR Purification Kit (Sangon Biotech, Shanghai, China) and sequenced using multiple primers including those which generated the PCR product and new internal primers developed by primer walking.

\section{Sequence analysis}

Contiguous sequence fragments were assembled using SeqMan (DNAStar) and Staden Package v1.7.0 [14]. Protein-coding (PCGs) and ribosomal RNA (rRNA) genes were initially identified using BLAST (Basic Local 
Table 1 List of PCR primer combinations used to amplify the mitochondrial genome of Paragyrodactylus variegatus

\begin{tabular}{|c|c|c|c|}
\hline Primer name & Gene & Sequence $\left(5^{\prime}-3^{\prime}\right)$ & Source \\
\hline $1 \mathrm{~F}(\mathrm{UND} 1 \mathrm{~F})^{*}$ & ND1 & CGHAAGGGNCCNAAHAAGGT & Huyse et al. (2007) [17] \\
\hline $1 R^{*}$ & $\mathrm{COI}$ & TAAACTTCTGGATGWCCAAAAAAT & This study \\
\hline 2 F(UNAD5F) & ND5 & TTRGARGCNATGCGBGCHCC & Huyse et al. (2007) [17] \\
\hline $2 \mathrm{R}$ & COIII & YCARCCTGAGCGAATTCARGCKGG & This study \\
\hline $3 \mathrm{~F}(\mathrm{U} 12 \mathrm{SF})^{*}$ & $\operatorname{rrnS}$ & CAGTGCCAGCAKYYGCGGTTA & Huyse et al. (2007) [17] \\
\hline 3R(UNAD5R)* & ND5 & GGWGCMCGCATNGCYTCYAA & Huyse et al. (2007) [17] \\
\hline $4 \mathrm{~F}$ & ND5 & ATGTGATTITTAGAGTTATGCTT & This study \\
\hline 4R(6RNAD5) & ND5 & AGGHTCTCTAACTTGGAAAGWTAGTAT & Huyse et al. (2008) [24] \\
\hline $5 \mathrm{~F}^{*}$ & COIII & TCTTCWRTTACAGYAACDTCCTA & This study \\
\hline $5 R^{*}$ & ND1 & AAACCTCATACCTAACTGCG & This study \\
\hline $6 \mathrm{~F}^{*}$ & $\mathrm{COI}$ & CTCCTITATCTGGTGCTCTGGG & This study \\
\hline $6 R^{*}$ & $\operatorname{rrnS}$ & GACGGGCGGTATGTACCTCTCT & This study \\
\hline F236 & COIII & TTGTITTGATTCCGTGA & This study \\
\hline F930 & CYTB & TTATCTTTGTGGTTCGTTCG & This study \\
\hline F1568 & CYTB & AGGTCAAAGATAGGTGGGTTAG & This study \\
\hline F2174 & ND4 & TATAGGAATTTTACCATTATTTA & This study \\
\hline F2855 & ND4 & CATGGCTTATCAGTTG & This study \\
\hline F3302 & tRNA $A^{G l n}$ & GGTAGCATAGGAGGTAAGGTTC & This study \\
\hline F8330 & $\mathrm{COI}$ & TTAGCGGGTATTTCAAGTA & This study \\
\hline F8920 & COl & GTATTATTCACTATAGGAGGGGTA & This study \\
\hline R4662 & ATP6 & ACGAAATAATAAAAATATAAAAAGT & This study \\
\hline R5283 & ND2 & TCCAGAAACTAACAATAAAGCAC & This study \\
\hline R6003 & tRNA ${ }^{\text {Val }}$ & ACCTAATGCTTGTAATG & This study \\
\hline R6599 & ND1 & AAACCTCATACCTAACTGCG & This study \\
\hline R7212 & tRNA $A^{\text {Pro }}$ & GCAGCCCTATCAGTAAGACC & This study \\
\hline R7941 & $\mathrm{COl}$ & ACCAAGCCCTACAAAACCTG & This study \\
\hline R10014 & $\mathrm{rrnL}$ & TCCCCATTCAGACAATCCTC & This study \\
\hline R10652 & $\operatorname{rrnS}$ & GCTGGCACTGTGACTTATCCTA & This study \\
\hline R11375 & COII & ATTGTAGGTAAAAAGGTTCAC & This study \\
\hline R12090 & ND6 & AAAAAGACAATAAGACCCACTA & This study \\
\hline R12752 & tRNA ${ }^{\text {Leu(UUR) }}$ & AACACTTTGTATTTGACGCT & This study \\
\hline R14014 & ND5 & AGGTTCAAGTAATGGTAGGTCT & This study \\
\hline
\end{tabular}

*The PCR primers for the long PCR fragment (>2 kb).

Alignment Search Tool) searches on GenBank, then by alignment with the published mitochondrial genomes of Gyrodactylus derjavinoides Malmberg, Collins, Cunningham and Jalali, 2007 (GenBank no. EU293891), G. salaris (GenBank no. DQ988931) and Gyrodactylus thymalli Zitnan, 1960 (GenBank no. EF527269). The secondary structure of the two rRNA genes was determined mainly by comparison with the published rRNA secondary structures of Dugesia japonica Ichikawa and Kawakatsu, 1964 (GenBank no. NC_016439) [15]. Proteincoding regions were translated with the echinoderm mitochondrial genetic code. The program tRNAscan-SE v1.21
(http://lowelab.ucsc.edu/tRNAscan-SE/) was used to identify transfer RNA (tRNA) genes and their structures [16], using the mito/chloroplast codon and setting the cove cutoff score to one. The tRNAs, which were not detected by tRNA scan-SE v1.21, were identified by comparing the sequence to Gyrodactylus [17,18]. Tandem Repeat Finder v4.07 was used to identify tandem repeats in non-coding regions [19]. The base composition, codon usage and genetic distance were calculated with MEGA v5.1 [20]. The nonsynonymous (Ka)/synonymous (Ks) values were estimated by the KaKs_Calculator v1.2 with the MA method [21]. 


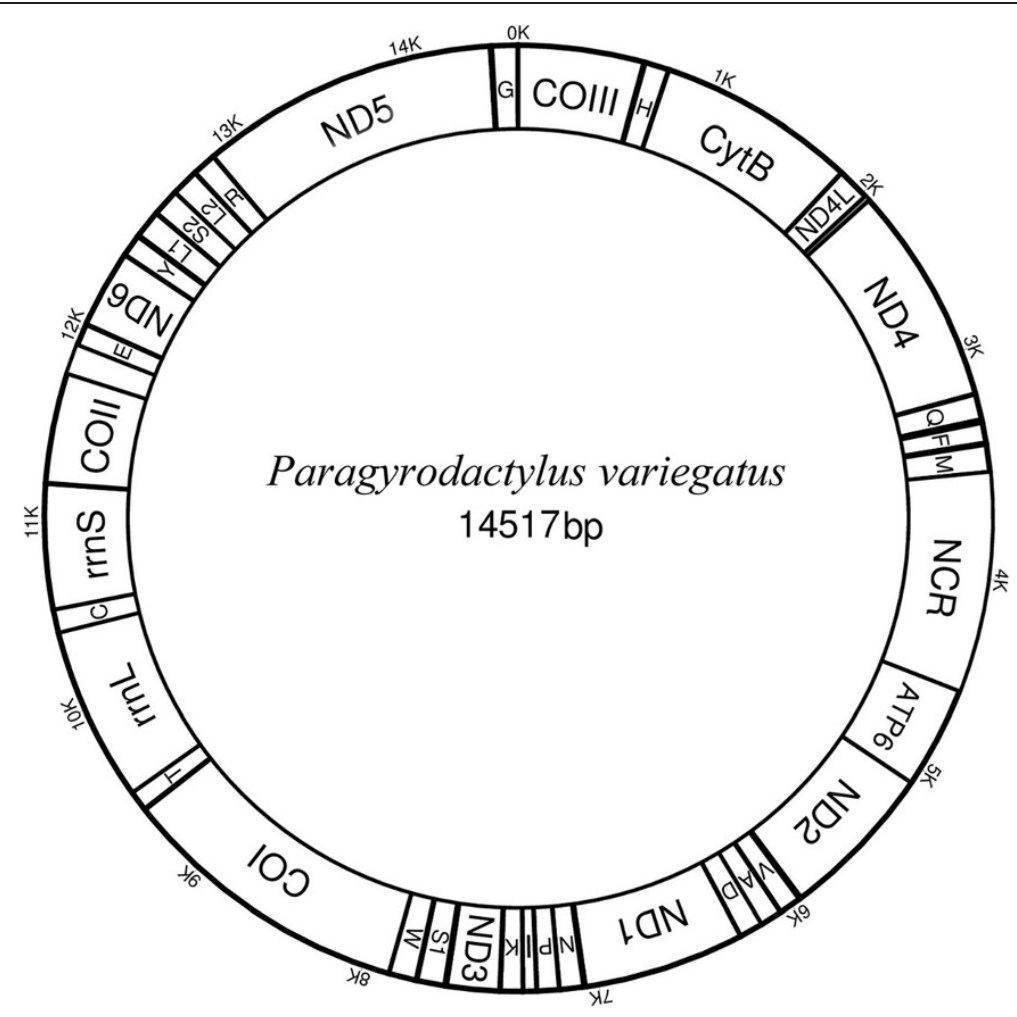

Figure 1 The gene map for the mitochondrial genome of Paragyrodactylus variegatus.

\section{Results}

Genome organization, base composition and gene order The circular mitochondrial genome of $P$. variegatus is 14,517 bp in size (GenBank no. KM067269) and contains 12 PCGs, 22 tRNAs, two rRNA and a single major non-coding region (NCR) (Figure 1). It lacks the ATP8 gene, and all the genes are transcribed from the same strand. The overall nucleotide composition is: $\mathrm{T}$ (45.8\%), C (9.5\%), A (30.4\%), G (14.2\%), with an overall $\mathrm{A}+\mathrm{T}$ content of $76.3 \%$ (Table 2).

The arrangement of rRNA and protein coding genes of $P$. variegatus is typical for gyrodactylids. However, the gene order of some tRNA genes is different: there are three tRNAs (tRNA ${ }^{\text {Gln }}$, tRNA ${ }^{\text {Phe }}$, tRNA ${ }^{\text {Met }}$ ) between ND4 and the major non-coding region and five tRNAs

Table 2 Base composition of the mitochondrial genome of Paragyrodactylus variegatus

\begin{tabular}{llllll}
\hline Genes & A\% & T\% & C\% & G\% & A + T\% \\
\hline Complete genome & 30.4 & 45.8 & 9.5 & 14.2 & 76.3 \\
Protein genes & 27.8 & 47.9 & 9.5 & 14.8 & 75.7 \\
rRNA genes & 34.4 & 40.7 & 10.6 & 14.2 & 75.1 \\
tRNA genes & 32.6 & 40.8 & 10.8 & 15.8 & 73.5 \\
Major non-coding region (NCR) & 42.5 & 40.9 & 7.2 & 9.4 & 83.4 \\
\hline
\end{tabular}

$\left(\mathrm{tRNA}^{\mathrm{Tyr}}, \mathrm{tRNA}^{\mathrm{Leu} 1}, \mathrm{tRNA}^{\mathrm{Ser} 2}, \mathrm{tRNA}^{\mathrm{Leu} 2}, \mathrm{tRNA}^{\mathrm{Arg}}\right)$ between ND6 and ND5 in P. variegatus, while Gyrodactylus spp. have one tRNA (tRNA ${ }^{\text {Phe }}$ ) and seven tRNAs $\left(\mathrm{tRNA}^{\mathrm{Tyr}}, \mathrm{tRNA}^{\mathrm{Leu} 1}, \mathrm{tRNA}^{\mathrm{Gln}}, \mathrm{tRNA}^{\mathrm{Met}}, \mathrm{tRNA}^{\text {Ser2 }}\right.$, $t_{R N A}{ }^{\text {Leu2 }}, t_{R N A}{ }^{A r g}$ ) in the same location, respectively.

\section{Protein coding genes and codon usage}

The total length of all 12 PCGs is 9,990 bp. The average $\mathrm{A}+\mathrm{T}$ content of PCGs is $75.7 \%$ (Table 2), ranging from $70.9 \%$ (COI) to $82.9 \%$ (ND2). ATG is the typical start codon, except for ND1 and COII, which begins with GTG and TTG, respectively (Table 3). All PCGs terminate with the stop codons TAA, while ND5 uses the codon TAG. The incomplete stop codons were not observed in $P$. variegatus.

The codon usage and relative synonymous codon usage (RSCU) values are summarized (Table 4). The most frequent amino acids in the PCGs of $P$. variegatus are as follows: Leucine (16.43\%), Phenylalanine (13.23\%), Serine $(12.48 \%)$, and Isoleucine $(10.67 \%)$. The frequency of Glutamine is especially low (0.69\%). The codons TTA (Leucine; 12.09\%) and TTT (Phenylalanine; 11.48\%) are the most frequently used codons. For the third position of the fourfold degenerate amino acid, codons ending with $\mathrm{T}$ are the most frequent. 
Table 3 The organization of the mitochondrial genome of Paragyrodactylus variegatus

\begin{tabular}{|c|c|c|c|c|c|c|c|}
\hline \multirow[t]{2}{*}{ Gene } & \multicolumn{2}{|c|}{ Position } & \multirow[t]{2}{*}{ Size (bp) } & \multicolumn{2}{|c|}{ Codon } & \multirow[t]{2}{*}{ Anticodon } & \multirow{2}{*}{$\begin{array}{l}\text { Intergenic } \\
\text { nucleotides }\end{array}$} \\
\hline & Form & To & & Start & Stop & & \\
\hline COIII & 1 & 639 & 639 & ATG & TAA & & / \\
\hline tRNA-His $(\mathrm{H})$ & 651 & 713 & 63 & & & GTG & 11 \\
\hline CYTB & 719 & 1798 & 1080 & ATG & TAA & & 5 \\
\hline ND4L & 1803 & 2057 & 255 & ATG & TAA & & 4 \\
\hline ND4 & 2030 & 3238 & 1209 & ATG & TAA & & -28 \\
\hline tRNA-Gln (Q) & 3245 & 3311 & 67 & & & TTG & 6 \\
\hline tRNA-Phe (F) & 3331 & 3397 & 67 & & & GAA & 19 \\
\hline tRNA-Met (M) & 3410 & 3476 & 67 & & & CAT & 12 \\
\hline NCR & 3477 & 4569 & 1093 & & & & 0 \\
\hline ATP6 & 4570 & 5082 & 513 & ATG & TAA & & 0 \\
\hline ND2 & 5084 & 5959 & 876 & ATG & TAA & & 1 \\
\hline tRNA-Val (V) & 5974 & 6040 & 67 & & & TAC & 14 \\
\hline tRNA-Ala (A) & 6047 & 6112 & 66 & & & TGC & 6 \\
\hline tRNA-Asp (D) & 6114 & 6178 & 65 & & & GTC & 1 \\
\hline ND1 & 6183 & 7073 & 891 & GTG & TAA & & 4 \\
\hline tRNA-Asn (N) & 7087 & 7155 & 69 & & & $\mathrm{GTT}$ & 13 \\
\hline tRNA-Pro (P) & 7159 & 7221 & 63 & & & TGG & 3 \\
\hline tRNA-Ile (I) & 7216 & 7283 & 68 & & & GAT & -6 \\
\hline tRNA-Lys (K) & 7288 & 7352 & 65 & & & CTT & 4 \\
\hline ND3 & 7361 & 7711 & 351 & ATG & TAA & & 8 \\
\hline tRNA-Ser ${ }^{(A G N)}(S 1)$ & 7726 & 7782 & 57 & & & $\mathrm{TCT}$ & 14 \\
\hline tRNA-Trp (W) & 7792 & 7858 & 67 & & & TCA & 9 \\
\hline $\mathrm{COI}$ & 7862 & 9409 & 1548 & ATG & TAA & & 3 \\
\hline tRNA-Thr (T) & 9418 & 9484 & 67 & & & TGT & 8 \\
\hline $\operatorname{rrnL}(16 S)$ & 9484 & 10443 & 960 & & & & -1 \\
\hline tRNA-Cys (C) & 10444 & 10503 & 60 & & & GCA & 0 \\
\hline $\operatorname{rrnS}(12 S)$ & 10505 & 11216 & 712 & & & & 1 \\
\hline COII & 11223 & 11804 & 582 & TTG & TAA & & 6 \\
\hline tRNA-Glu (E) & 11955 & 12018 & 64 & & & TTC & 150 \\
\hline ND6 & 12025 & 12501 & 477 & ATG & TAA & & 6 \\
\hline tRNA-Tyr (Y) & 12507 & 12573 & 67 & & & GTA & 5 \\
\hline tRNA-Leu ${ }^{(\mathrm{CUN})}(\mathrm{L} 1)$ & 12585 & 12650 & 66 & & & TAG & 11 \\
\hline tRNA-Ser ${ }^{(\mathrm{UCN})}(\mathrm{S} 2)$ & 12657 & 12716 & 60 & & & TGA & 6 \\
\hline tRNA-Leu ${ }^{(\mathrm{UUR})}(\mathrm{L} 2)$ & 12719 & 12788 & 70 & & & TAA & 2 \\
\hline tRNA-Arg (R) & 12794 & 12860 & 67 & & & TCG & 5 \\
\hline ND5 & 12865 & 14433 & 1569 & ATG & TAG & & 4 \\
\hline tRNA-Gly (G) & 14446 & 14513 & 68 & & & TCC & 12 \\
\hline
\end{tabular}

Ribosomal and transfer RNA genes

The length of large ribosomal subunit (rrnL) and small ribosomal subunit ( $\mathrm{rrnS}$ ) genes of $P$. variegatus are $960 \mathrm{bp}$ and $712 \mathrm{bp}$, respectively (Table 3). The A+T contents of the rrnL and rrnS of P. variegatus are $75.0 \%$ and $75.3 \%$, respectively. The predicted secondary structure of rrnL and rrnS of $P$. variegatus is shown in Figure 2 and Figure 3. The secondary structures of these regions contain six and three structural domains, respectively. But domain I of the rrnL lacks a large region at the $5^{\prime}$ end gene, 
Table 4 Codon usage for the $\mathbf{1 2}$ mitochondrial proteins of Paragyrodactylus variegatus

\begin{tabular}{|c|c|c|c|c|c|c|c|}
\hline Codon(AA) & $\mathbf{N}$ & $\%$ & $\mathrm{RSCU}$ & Codon(AA) & $\mathbf{N}$ & $\%$ & $\mathrm{RSCU}$ \\
\hline UUU(F) & 381 & 11.48 & 1.74 & UAU(Y) & 180 & 5.42 & 1.72 \\
\hline UUC(F) & 58 & 1.75 & 0.26 & UAC(Y) & 29 & 0.87 & 0.28 \\
\hline UUA(L) & 401 & 12.09 & 4.41 & $\operatorname{UAA}(*)$ & 0 & 0.00 & 0 \\
\hline UUG(L) & 39 & 1.18 & 0.43 & UAG $(*)$ & 0 & 0.00 & 0 \\
\hline CUU(L) & 68 & 2.05 & 0.75 & $\mathrm{CAU}(\mathrm{H})$ & 45 & 1.36 & 1.7 \\
\hline$C \cup C(L)$ & 7 & 0.21 & 0.08 & $\mathrm{CAC}(\mathrm{H})$ & 8 & 0.24 & 0.3 \\
\hline $\mathrm{CUA}(\mathrm{L})$ & 27 & 0.81 & 0.3 & $\mathrm{CAA}(\mathrm{Q})$ & 14 & 0.42 & 1.22 \\
\hline CUG(L) & 3 & 0.09 & 0.03 & $\mathrm{CAG}(\mathrm{Q})$ & 9 & 0.27 & 0.78 \\
\hline$A \cup U(I)$ & 175 & 5.27 & 1.48 & $\operatorname{AAU}(\mathrm{N})$ & 103 & 3.10 & 1.67 \\
\hline $\mathrm{AUC}(\mathrm{I})$ & 11 & 0.33 & 0.09 & $\mathrm{AAC}(\mathrm{N})$ & 18 & 0.54 & 0.29 \\
\hline $\mathrm{A} \cup \mathrm{A}(\mathrm{I})$ & 168 & 5.06 & 1.42 & $\mathrm{AAA}(\mathrm{N})$ & 64 & 1.93 & 1.04 \\
\hline$A \cup G(M)$ & 68 & 2.05 & 1 & $\mathrm{AAG}(\mathrm{K})$ & 48 & 1.45 & 1 \\
\hline GUU(V) & 150 & 4.52 & 2.4 & GAU(D) & 54 & 1.63 & 1.59 \\
\hline GUC(V) & 8 & 0.24 & 0.13 & GAC(D) & 14 & 0.42 & 0.41 \\
\hline GUA(V) & 81 & 2.44 & 1.3 & $\mathrm{GAA}(\mathrm{E})$ & 37 & 1.12 & 1.32 \\
\hline GUG(V) & 11 & 0.33 & 0.18 & $\mathrm{GAG}(\mathrm{E})$ & 19 & 0.57 & 0.68 \\
\hline UCU(S) & 114 & 3.44 & 2.2 & UGU(C) & 65 & 1.96 & 1.83 \\
\hline UCC(S) & 9 & 0.27 & 0.17 & UGC(C) & 6 & 0.18 & 0.17 \\
\hline UCA(S) & 65 & 1.96 & 1.26 & UGA(W) & 58 & 1.75 & 1.55 \\
\hline UCG(S) & 3 & 0.09 & 0.06 & UGG(W) & 17 & 0.51 & 0.45 \\
\hline $\operatorname{CCU}(\mathrm{P})$ & 38 & 1.15 & 2.03 & $\mathrm{CGU}(\mathrm{R})$ & 33 & 0.99 & 3 \\
\hline $\operatorname{CCC}(\mathrm{P})$ & 2 & 0.06 & 0.11 & $\operatorname{CGC}(\mathrm{R})$ & 4 & 0.12 & 0.36 \\
\hline$C C A(P)$ & 34 & 1.02 & 1.81 & $C G A(R)$ & 5 & 0.15 & 0.45 \\
\hline $\operatorname{CCG}(P)$ & 1 & 0.03 & 0.05 & $C G G(R)$ & 2 & 0.06 & 0.18 \\
\hline$A C U(T)$ & 58 & 1.75 & 2.37 & $A G U(S)$ & 104 & 3.13 & 2.01 \\
\hline$A C C(T)$ & 9 & 0.27 & 0.37 & AGC(S) & 12 & 0.36 & 0.23 \\
\hline$A C A(T)$ & 30 & 0.90 & 1.22 & $A G A(S)$ & 81 & 2.44 & 1.57 \\
\hline $\operatorname{ACG}(T)$ & 1 & 0.03 & 0.04 & AGG(S) & 26 & 0.78 & 0.5 \\
\hline GCU(A) & 33 & 0.99 & 1.97 & GGU(G) & 90 & 2.71 & 2.05 \\
\hline GCC (A) & 7 & 0.21 & 0.42 & $\mathrm{GGC}(\mathrm{G})$ & 18 & 0.54 & 0.41 \\
\hline$G C A(A)$ & 25 & 0.75 & 1.49 & $\mathrm{GGA}(\mathrm{G})$ & 46 & 1.39 & 1.05 \\
\hline GCG $(A)$ & 2 & 0.06 & 0.12 & GGG(G) & 22 & 0.66 & 0.5 \\
\hline
\end{tabular}

A total of 3318 codons for $P$. variegatus were analyzed, excluding the stop codons. AA, amino acid; $\mathrm{N}$, number of used codon; $\%=\mathrm{N} / 3318$; RSCU, relative synonymous codon usage.

and the domain III is absent in the secondary structure of rrnL of $P$. variegatus.

The 22 tRNA genes of $P$. variegatus vary in length from 57 to 70 nucleotides. Sequences of tRNA ${ }^{\text {Ile }}$ and tRNA $^{\text {Thr }}$ genes overlap with neighboring genes (Table 3). All of the 22 tRNAs have the typical cloverleaf secondary structure, except for tRNA ${ }^{\text {Cys }}$, tRNA ${ }^{\text {Ser1 }}$ and tRNA $^{\text {Ser2 }}$ in which each have unpaired dihydrouridine (DHU) arm.

\section{Synonymous and nonsynonymous substitutions and genetic distance}

The $\mathrm{Ka} / \mathrm{Ks}$ values for all 12 PCGs of $P$. variegatus versus Gyrodactylus spp. are presented, which all are less than 0.3 . The highest average $\mathrm{Ka} / \mathrm{Ks}$ value is ND2 (0.29), while the $\mathrm{Ka} / \mathrm{Ks}$ ratios of half the PCGs are low (Ka/ $\mathrm{Ks}<0.1)$. The genetic distance between $P$. variegatus and the three reported species of Gyrodactylus ( $G$. thymalli, G. salaris and G. derjavinoides) are much greater than among the three species of Gyrodactylus (Figure 4). The maximum divergence occurs in ND5 gene $(48.9 \%)$ between $P$. variegatus and G. salaris. In addition, the genetic distances of rRNA genes are lower than protein genes (Figure 4).

\section{Non-coding regions}

The major non-coding region is $1,093 \mathrm{bp}$ in size, which is highly enriched in AT (83.4\%). This non-coding region can be subdivided into six parts including three junctions by the sequence pattern (Figure 5 ). The sequence of part I and part II is homologous with $81.7 \%$ sequence identity. Part III contains six identical repeat units of 40 bp sequence with some sequence modifications: one substitution at the fifth position (the initial repeat unit), three substitutions at the 223rd, 227th and 237th positions and two insertions at the 222nd and 225th positions (the terminal repeat unit). The repeat unit of part III was able to fold into a stem-loop secondary structure. Some predicted structural elements were also found in the sequence of part I and II (Figure 6). In addition, 30 short non-coding regions, all $<151 \mathrm{bp}$, occur in the mitochondrial genome of $P$. variegatus (Table 3 ).

\section{Discussion}

\section{Characteristics of the mitochondrial genome}

The mitochondrial genome of $P$. variegatus is $222 \mathrm{bp}$ shorter than that of $G$. derjavinoides, but well within the length range of parasitic flatworms [22,23]. Differing number and length of the major non-coding region is the main factor that contributes to this difference in genome size. The overall $\mathrm{A}+\mathrm{T}$ content of $P$. variegatus is higher than that of all reported mitochondrial genomes of monogeneans. The average $\mathrm{Ka} / \mathrm{Ks}$ values of genes encoding 3 subunits of cytochrome c oxidase and the cytochrome b subunit of cytochrome bc1 complex are lower than genes encoding subunits of the NADH dehydrogenase complex (with the exception of ND1), especially COI and Cytb genes. This feature demonstrates COI, COII, COIII and Cytb genes are more strongly effected by purifying selection pressure compared to subunits of the NADH dehydrogenase genes (except ND1), which is similar to the findings of Huyse et al. [24] for Gyrodactylus derjavinoides. The degree of functional constraints might be a reason for corresponding 


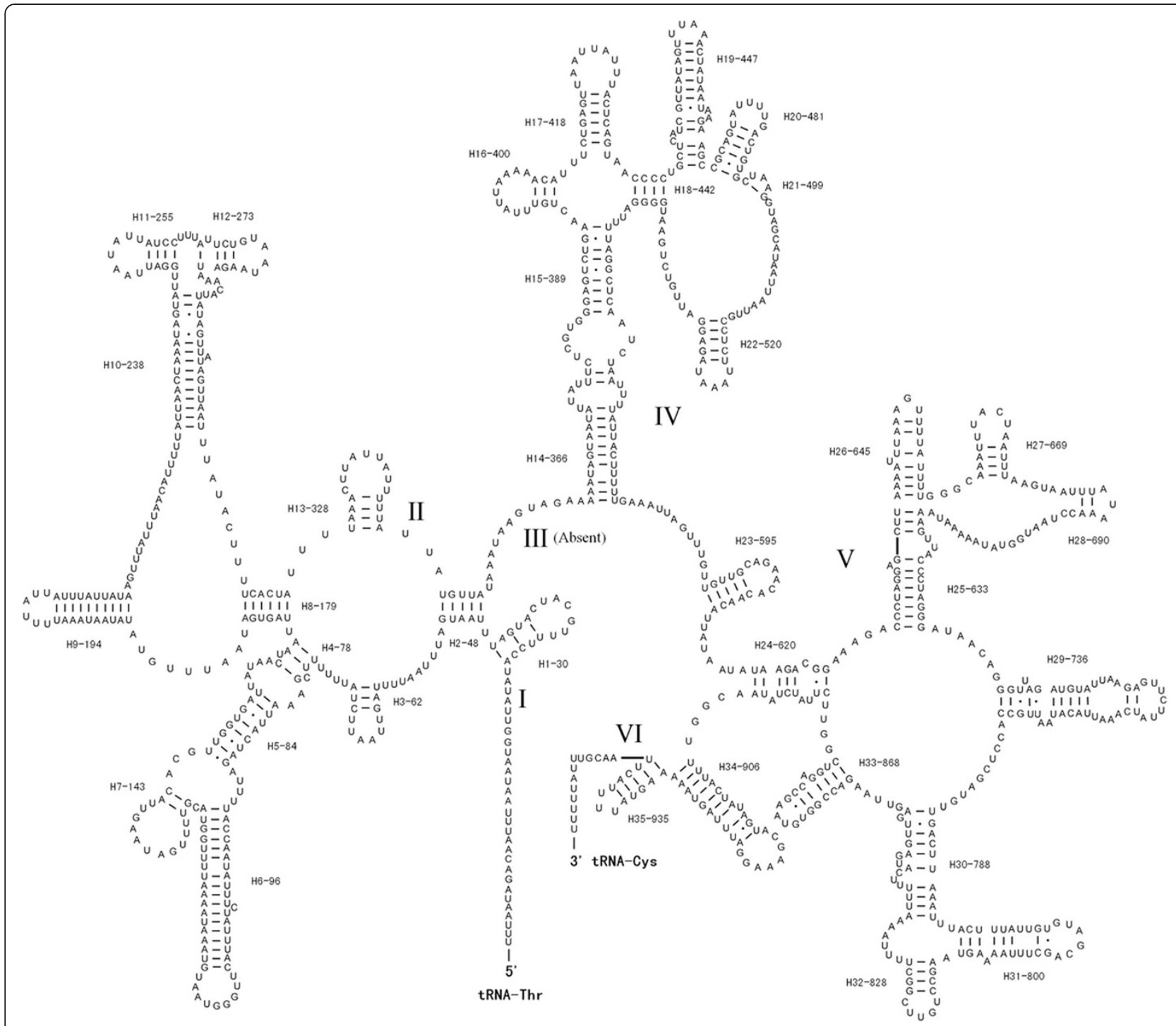

Figure 2 Inferred secondary structure of the mitochondrial rrnL gene for Paragyrodactylus variegatus.

degree sequence variations of protein genes. The low $\mathrm{Ka} / \mathrm{Ks}$ values and genetic distance of $\mathrm{COI}$ and Cytb genes also imply that both genes could be used as a useful marker for analyses at higher taxonomic levels. Although sizes of rrnL and rrnS are very similar among Gyrodactylus spp. and P. variegatus, the sequence similarities are not high. These discrepancies may reflect the variable helices or loops that exist in the rRNA structure.

\section{The major non-coding region}

The mitochondrial genome of $P$. variegatus includes one major non-coding region, which has been frequently observed in other invertebrates. It contains a high $\mathrm{A}+\mathrm{T}$ content and tandem repeat sequences which could not be found in large non-coding regions ( $>500 \mathrm{bp}$ ) of the published mitochondrial genomes of monopisthocotyleans. We found that length and number of tandem repeat units are similar to those observed in Microcotyle sebastis Goto, 1894 [25], contradicting the study of Zhang et al. [26] that reported the length and number of repeated motifs were different in the mitochondrial non-coding regions of monopisthocotylids and polyopisthocotylids.

A non-coding region with high $\mathrm{A}+\mathrm{T}$ content and pertinent elements usually corresponds to the control region for replication and transcription initiation. In the major non-coding region of $P$. variegatus, we found identical patterns within part I and part II. The patterns have only two nucleotide modifications with $2.3 \%$ sequence 


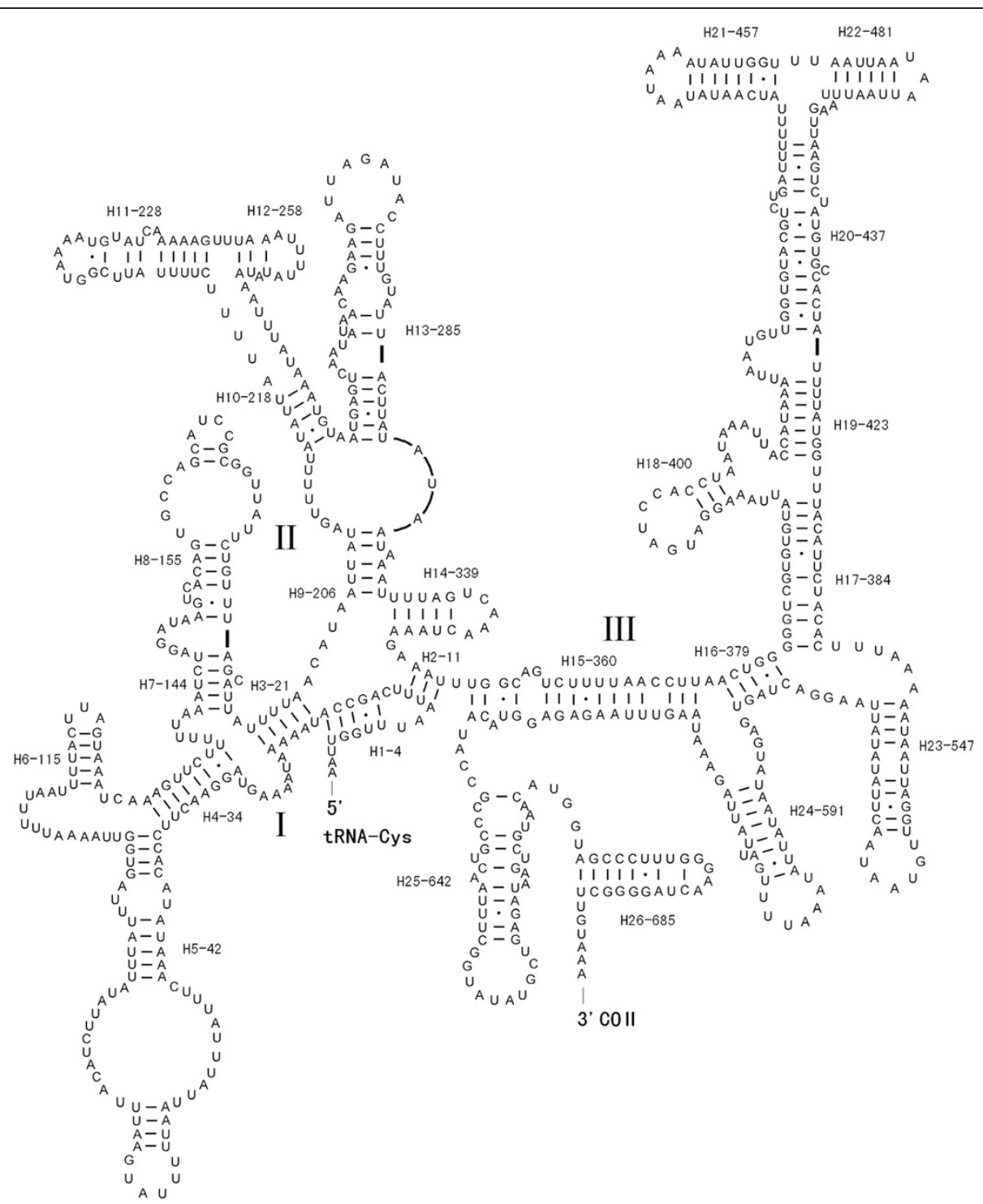

Figure 3 Inferred secondary structure of the mitochondrial rrnS gene for Paragyrodactylus variegatus.

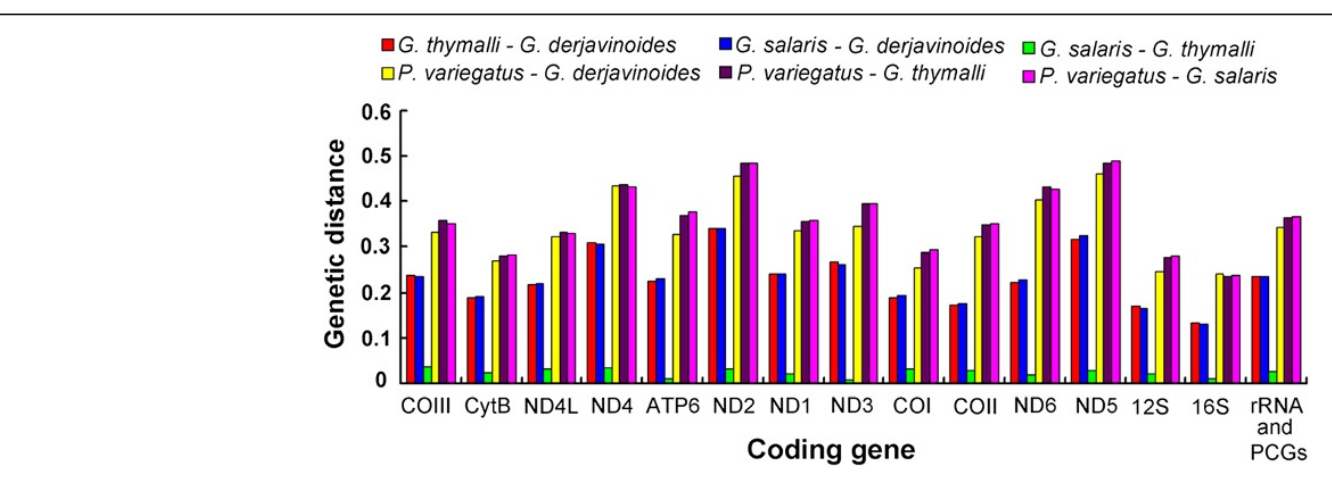

Figure 4 The genetic distance of protein and rRNA genes of Paragyrodactylus variegatus and Gyrodactylus spp. 


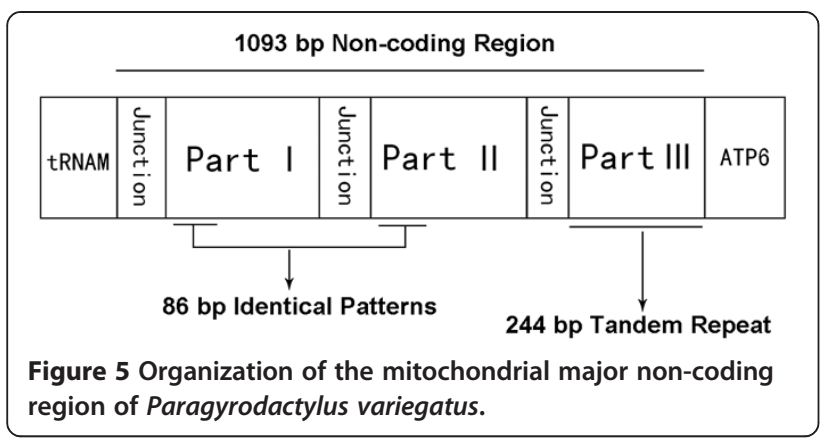

discrepancy; however, the overall difference between the whole sequence of part I and part II is $18.3 \%$. The highly conserved part of the non-coding region is believed to have a functional role. The patterns contain poly- $\mathrm{T}$ stretches, a stem-loop structure and some surrounding structure elements (A + T-rich segment and G[A] nT) (Figure 6) which are typical of control regions in insects [27-30]. Although typical control regions are not readily identifiable within the mitochondrial genome of flatworms [17], the predicted secondary structure, conserved element, repeat sequences and high A $+\mathrm{T}$ content of major non-coding region in $P$. variegatus implies that this region might play an important role in the initiation of replication and transcription.

In addition, through alignment of non-coding regions sequences between Gyrodactylus spp. and P. variegatus, we found some conserved motifs in each species with the overall similarity among them being $72.1 \%$. The conserved motifs ( $>5 \mathrm{bp}$ ) mainly existed in the $\mathrm{A}+\mathrm{T}$-rich segment and G + A-rich segment. However, whether or not the conserved motifs are present in other species of Gyrodactylidae needs to be assessed with a broader taxon sample.

\section{Gene arrangements and possible evolutionary mechanisms}

Five available mitochondrial gene arrangements of monopisthocotylids are shown in Figure 7. The arrangement

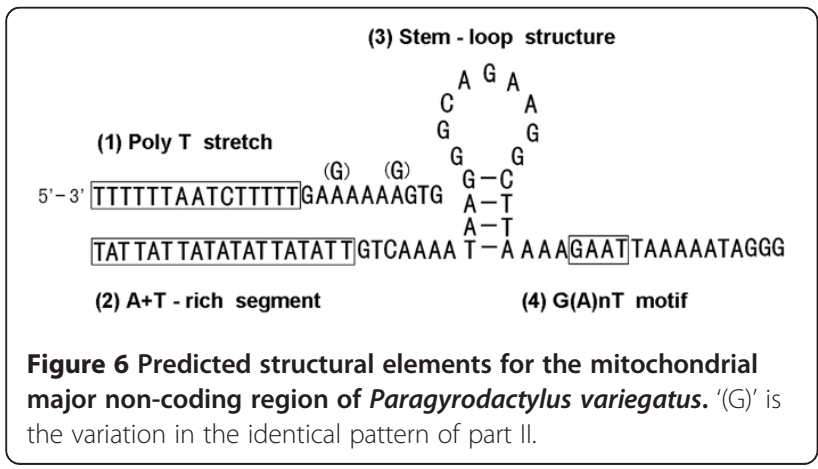

of all rRNA and protein coding genes are identical throughout all samples, however, the tRNA genes differ in arrangement showing some translocation, particularly long-range translocation. No notable rearrangement hot spot could be found in gene arrangements of monopisthocotylids, however, the major change of gene arrangement among polyopisthocotylids is limited in the COIII-ND5 junction as a gene rearrangement hot spot [26]. Two gene clusters (tRNA ${ }^{\text {Asn }}$-tRNA ${ }^{\text {Pro }}$-tRNA ${ }^{\text {Ile }}$-tRNA ${ }^{\text {Lys }}$ and rrnLtRNA ${ }^{\text {Cys }}$-rrnS) were found to be conserved in all mitochondrial genomes of monopisthocotyleans. Nevertheless, the tRNA ${ }^{\text {Lys }}$ and RNAA $^{\text {Cys }}$ were found in the gene rearrangement hot spot of polyopisthocotyleans. The conserved gene clusters could potentially be a marker used to help define the Polyopisthocotylea and Monopisthocotylea within the monogenea, as well as providing information for a deeper understanding of the evolution of monogenean mitochondrial genomes.

Gene rearrangement can be mainly explained by three mechanisms: Duplication and Random Loss Model [31,32], Duplication and Nonrandom Loss Model [33] and Recombination Model [34]. The variation (tRNA ${ }^{\text {Gln }}$, tRNA $^{\text {Met }}$ and NCR) of mitochondrial gene order occurring between P. variegatus and Gyrodactylus spp. could be explained by the duplication and random loss model and recombination model together with the parsimonious scenario. We assume that the process contains three steps: one tandem duplication, random loss, followed by intramitochondrial recombination (Figure 8). We prefer this mechanism for the following reasons: the duplicate NCRs in the mitochondrial genomes of most metazoans can be explained by the duplication and random loss model, but the stepwise mechanism described above is more appropriate to interpret the duplicated NCRs and long-range translocation, meanwhile the rest of the genes remain in their original state. Furthermore, there are several examples of mitochondrial recombination in animals [35-38], and a similar mechanism accounts for the gene rearrangement of other metazoans $[39,40]$. In addition, the tRNA ${ }^{\text {Met }}$ genes of Gyrodactylus spp. are clearly homologous to the tRNA ${ }^{\text {Met }}$ gene of $P$. variegatus with $80.6 \%$ sequence similarity. However, the tRNA ${ }^{\text {Gln }}$ region does have low sequence similarity (66.2\%) between the mitochondrial genomes of Gyrodactylus spp. and $P$. variegatus, so we cannot be certain that the translocation event happened. As more mitochondrial genomes of gyrodactylids become available, all of the above hypotheses should be tested with respect to gene orders.

\section{Conclusions}

The characteristics of the mitochondrial genome of $P$. variegatus are notably different from Gyrodactylus spp., including the gene order, which is similar to 


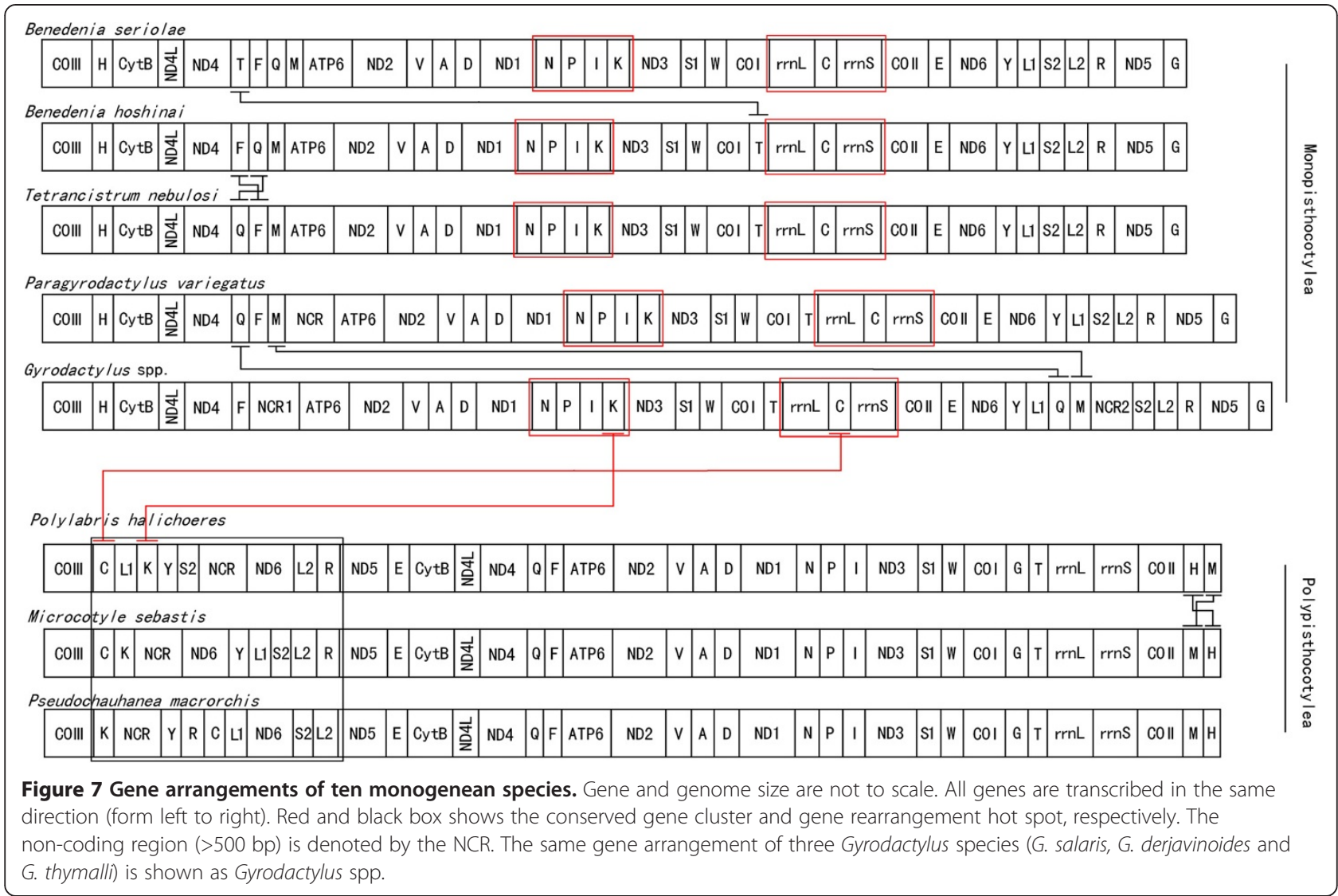

other monopisthocotylids. The overall average genetic distance between Paragyrodactylus and Gyrodactylus based on the rRNA and 12 protein coding genes is remarkably greater than within Gyrodactylus. All of these features support Paragyrodactylus as a distinct genus.
Considering their specific distribution and hosts, we tend towards the view of You et al. [8] that Paragyrodactylus is a relict freshwater lineage of viviparous monogenean isolated in the high plateaus of central Asia on closely related river loaches.

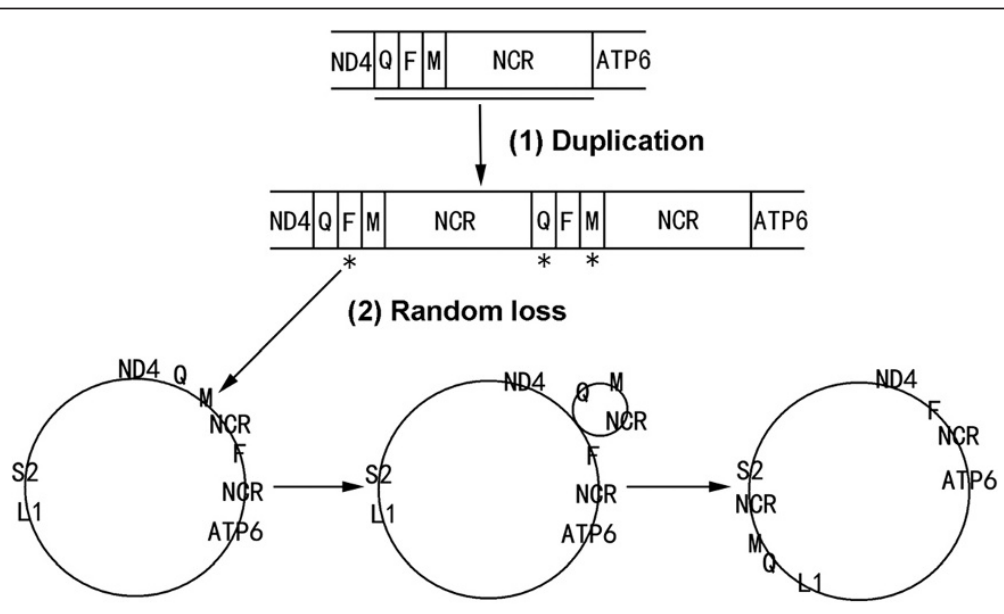

(3) Intramitochondrial recombination

Figure 8 Possible mechanism of mitochondrial gene rearrangements occurring in Paragyrodactylus variegatus and Gyrodactylus spp. 


\section{Competing interests}

The authors declare that they have no competing interests.

\section{Authors' contributions}

FY performed the experiments and analyzed the data. FY, SDK, DKC and PY co-drafted the manuscript and all have read and approved the final version.

\section{Acknowledgments}

The authors would like to thank Dr. Yuan Huang (College of Life Science, Shaanxi Normal University) for assistance with the analytic software. This research was supported by the National Natural Science Foundation of China (31372158).

\section{Author details}

${ }^{1}$ Co-Innovation Center for Qinba regions' sustainable development, College of Life Science, Shaanxi Normal University, Xi'an 710062, China. ${ }^{2}$ Department of Biology, Dalhousie University, Halifax, Nova Scotia B3H 4 J1, Canada. ${ }^{3}$ Department of Biology, Saint Mary's University, Halifax, Nova Scotia B3H 3C3, Canada.

Received: 6 May 2014 Accepted: 4 August 2014

Published: 17 August 2014

\section{References}

1. Johnsen BO, Jensen AJ: The Gyrodactylus story in Norway. Aquaculture 1991, 98:289-302.

2. Mo TA, Norheim $\mathrm{K}$ : The surveillance and control programme for Gyrodactylus salaris in Atlantic salmon and rainbow trout in Norway. In Annual Report 2004. Oslo, Norway: National Veterinary Institute; 2005:137-139.

3. Bakke TA, Cable J, Harris PD: The biology of gyrodactylid monogeneans: the "Russian Doll-killers". Adv Parasitol 2007, 64:161-376.

4. Ziętara MS, Huyse T, Lumme J, Volckaert FA: Deep divergence among subgenera of Gyrodactylus inferred from rDNA ITS region. Parasitology 2002, 124:39-52.

5. Matejusová I, Gelnar M, Verneau O, Cunningham CO, Littlewood DTJ: Molecular phylogenetic analysis of the genus Gyrodactylus (Platyhelminthes: Monogenea) inferred from rDNA ITS region: subgenera versus species groups. Parasitology 2003, 127:603-611.

6. Vanhove MPM, Tessens B, Schoelinck C, Jondelius U, Littlewood DTJ, Artois T, Huyse T: Problematic barcoding in flatworms: A case-study on monogeneans and rhabdocoels (Platyhelminthes). Zookeys 2013, 365:355-379.

7. Bueno-Silva M, Boeger WA: Neotropical Monogenoidea. 58. Three new species of Gyrodactylus (Gyrodactylidae) from Scleromystax spp. (Callichthyidae) and the proposal of COll gene as an additional fragment for barcoding gyrodactylids. Folia Parasitol 2014, 61:213-222.

8. You P, King SD, Ye F, Cone DK: Paragyrodactylus variegatus $\mathrm{n} . \mathrm{sp}$. (Gyrodactylidae) from Homatula variegata (Dabry de Thiersant, 1874) (Nemacheilidae) in central China. J Parasitol 2014, 100:350-355.

9. Kritsky DC, Boeger WA: Phylogeny of the Gyrodactylidae and the phylogenetic status of Gyrodactylus Nordmann, 1832 (Platyhelminthes: Monogenoidea). In Taxonomy, ecology and evolution of metazoan parasites (Livre hommage à Louis Euzet). Edited by Tome II, Combes C, Jourdane J. Perpignan, France: Presses Universitaire Perpignan; 2003:37-58.

10. Elson JL, Lightowlers RN: Mitochondrial DNA clonality in the dock: can surveillance swing the case? Trends Genet 2006, 22:603-607.

11. Gissi C, lannelli F, Pesole G: Evolution of the mitochondrial genome of Metazoa as exemplified by comparison of congeneric species. Heredity 2008, 101:301-320

12. Lavrov DV, Lang BF: Poriferan mtDNA and animal phylogeny based on mitochondrial gene arrangements. Syst Biol 2005, 54:651-659.

13. Boore JL, Brown WM: Big trees from little genomes: mitochondrial gene order as a phylogenetic tool. Curr Opin Genet Dev 1998, 8:668-674.

14. Staden R, Beal KF, Bonfield JK: The Staden package, 1998. Methods in Molecular Biology. In Bioinformatics Methods and Protocols. Edited by Misener S, Krawetz SA. Totowa, NJ: The Humana Press Inc; 1998:115-130.

15. Sakai M, Sakaizumi M: The complete mitochondrial genome of Dugesia japonica (Platyhelminthes; Order Tricladida). Zoolog Sci 2012, 29:672-680
16. Lowe TM, Eddy SR: tRNAscan-SE: a program for improved detection of transfer RNA genes in genomic sequence. Nucleic Acids Res 1997, 25:955-964

17. Huyse T, Plaisance L, Webster BL, Mo TA, Bakke TA, Bachmann L, Littlewood DTJ: The mitochondrial genome of Gyrodactylus salaris (Platyhelminthes: Monogenea), a pathogen of Atlantic salmon (Salmo salar). Parasitology 2007, 134:739-747

18. Plaisance L, Huyse T, Littlewood DTJ, Bakke TA, Bachmann L: The complete mitochondrial DNA sequence of the monogenean Gyrodactylus thymalli (Platyhelminthes: Monogenea), a parasite of grayling (Thymallus thymallus). Mol Biochem Parasitol 2007, 154:190-194.

19. Benson G: Tandem repeats finder: a program to analyze DNA sequences. Nucleic Acids Res 1999, 27:573-580.

20. Tamura K, Peterson D, Peterson N, Stecher G, Nei M, Kumar S: MEGA5: molecular evolutionary genetics analysis using maximum likelihood, evolutionary distance, and maximum parsimony methods. Mol Biol Evol 2011, 28:2731-2739.

21. Zhang Z, Li J, Zhao XQ, Wang J, Wong GK, Yu J: KaKs_Calculator: calculating $\mathrm{Ka}$ and $\mathrm{Ks}$ through model selection and model averaging. Genomics Proteomics Bioinformatics 2006, 4:259-263.

22. Le TH, Humair PF, Blair D, Agatsuma T, Littlewood DTJ, McManus DP: Mitochondrial gene content, arrangement and composition compared in African and Asian schistosomes. Mol Biochem Parasitol 2001, 117:61-71.

23. Le TH, Blair D, McManus DP: Mitochondrial genomes of parasitic flatworms. Trends Parasitol 2002, 18:206-213.

24. Huyse T, Buchmann K, Littlewood DTJ: The mitochondrial genome of Gyrodactylus derjavinoides (Platyhelminthes: Monogenea) - a mitogenomic approach for Gyrodactylus species and strain identification. Gene 2008, 417:27-34.

25. Park JK, Kim KH, Kang S, Kim W, Eom KS, Littlewood DTJ: A common origin of complex life cycles in parasitic flatworms: evidence from the complete mitochondrial genome of Microcotyle sebastis (Monogenea: Platyhelminthes). BMC Evol Biol 2007, 7:11

26. Zhang J, Wu X, Xie M, Li A: The complete mitochondrial genome of Pseudochauhanea macrorchis (Monogenea: Chauhaneidae) revealed a highly repetitive region and a gene rearrangement hot spot in Polyopisthocotylea. Mol Biol Rep 2012, 39:8115-8125.

27. Goddard JM, Wolstenholme DR: Origin and direction of replication in mitochondrial DNA molecules from the genus Drosophila. Nucleic Acids Res 1980, 8:741-757.

28. Zhang DX, Szymura JM, Hewitt GM: Evolution and structure conservation of the control region of insect mitochondrial DNA. J Mol Evol 1995, 40:382-391

29. Zhang DX, Hewitt GM: Insect mitochondrial control region: a review of its structure, evolution and usefulness in evolutionary studies. Biochem Syst Ecol 1997, 25:99-120

30. Wei SJ, Shi M, Chen XX, Sharkey MJ, Achterberg CV, Ye GY, He JH: New views on strand asymmetry in insect mitochondrial genomes. PLOS One 2010, 5:e12708.

31. Moritz C, Brown WM: Tandem duplications in animal mitochondrial DNAs: variation in incidence and gene content among lizards. Proc Natl Acad SCi USA 1987, 84:7183-7187

32. Boore JL: The duplication/random loss model for gene rearrangement exemplified by mitochondrial genomes of deuterostome animals. In Computational biology series. Vol. 1. Dordrecht (The Netherlands). Edited by Sankoff D, Nadeau J. Dordrecht, Boston, and London: Kluwer Academic Publishers; 2000:133-147.

33. Lavrov DV, Boore JL, Brown WM: Complete mtDNA sequences of two millipedes suggest a new model for mitochondrial gene rearrangement: duplication and nonrandom loss. Mol Biol Evol 2002, 19:163-169.

34. Dowton M, Campbell NJH: Intramitochondrial recombination - is it why some mitochondrial genes sleep around? Trends Ecol Evol 2001, 16:269-271

35. Thyagarajan B, Padua RA, Campbell C: Mammalian mitochondria possess homologous DNA recombination activity. J Biol Chem 1996, 271:27536-27543.

36. Lunt DF, Hyman BC: Animal mitochondrial DNA recombination. Nature 1997, 387:247

37. Rawson PD: Nonhomologous recombination between the large unassigned region of the male and female mitochondrial genomes in the mussel, Mytilus trossulus. J Mol Evol 2005, 61:717-732. 
38. Tsaousis AD, Martin DP, Ladoukakis ED, Posada D, Zouros E: Widespread recombination in published animal mtDNA sequences. Mol Biol Evol 2005, 22:925-933.

39. Chen WJ, Bu Y, Carapelli A, Dallai R, Li S, Yin WY, Luan YX: The mitochondrial genome of Sinentomon erythranum (Arthropoda: Hexapoda: Protura): an example of highly divergent evolution. BMC Evol Biol 2011, 11:246.

40. Kurabayashi A, Sumida M, Yonekawa H, Glaw F, Vences M, Hasegawa M: Phylogeny, recombination, and mechanisms of stepwise mitochondrial genome reorganization in mantellid frogs from Madagascar. Mol Biol Evol 2008, 25:874-891.

doi:10.1186/1756-3305-7-377

Cite this article as: Ye et al:: The mitochondrial genome of

Paragyrodactylus variegatus (Platyhelminthes: Monogenea): differences

in major non-coding region and gene order compared to Gyrodactylus.

Parasites \& Vectors 2014 7:377.

\section{Submit your next manuscript to BioMed Central and take full advantage of:}

- Convenient online submission

- Thorough peer review

- No space constraints or color figure charges

- Immediate publication on acceptance

- Inclusion in PubMed, CAS, Scopus and Google Scholar

- Research which is freely available for redistribution 